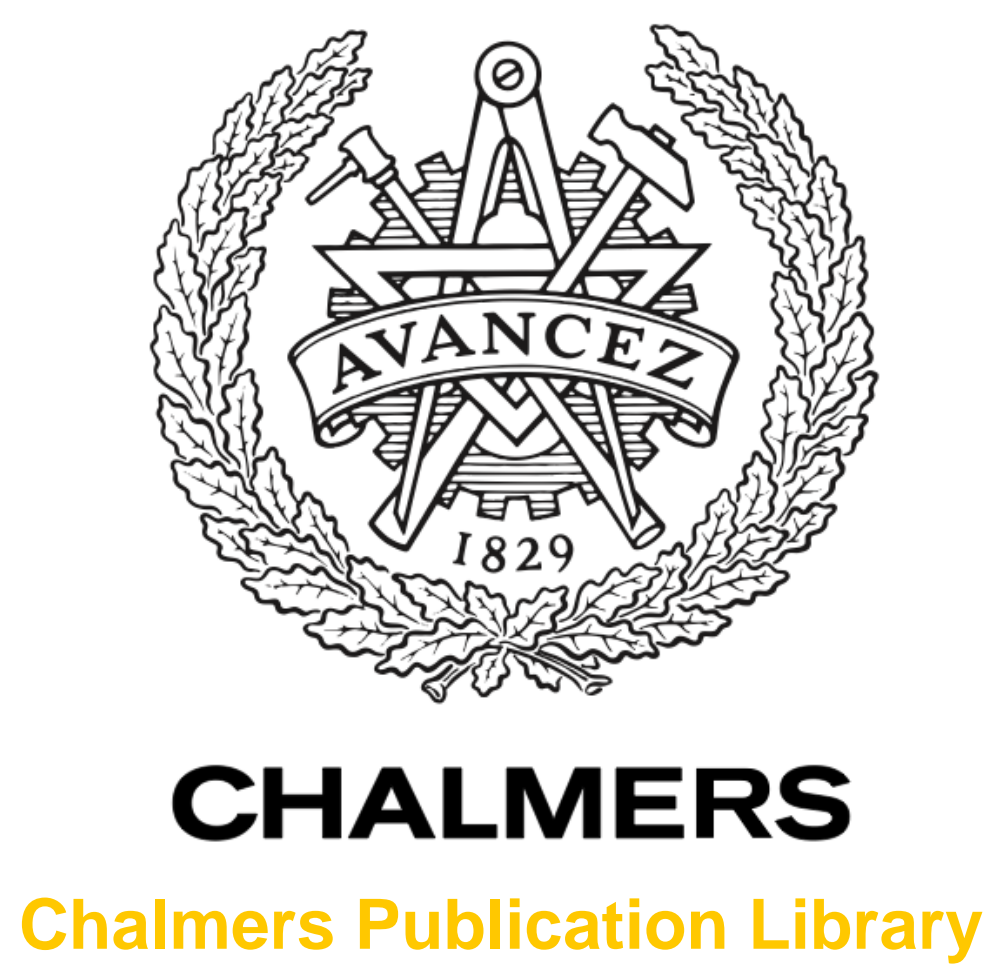

\title{
Opportunities for microbial electrochemistry in municipal wastewater treatment - an overview
}

This document has been downloaded from Chalmers Publication Library (CPL). It is the author's version of a work that was accepted for publication in:

Water Science and Technology (ISSN: 0273-1223)

Citation for the published paper:

Modin, O. ; Gustavsson, D. (2014) "Opportunities for microbial electrochemistry in municipal wastewater treatment - an overview". Water Science and Technology, vol. 69(7), pp. 1359-1372.

Downloaded from: http://publications.lib.chalmers.se/publication/197084

Notice: Changes introduced as a result of publishing processes such as copy-editing and formatting may not be reflected in this document. For a definitive version of this work, please refer to the published source. Please note that access to the published version might require a subscription. 


\title{
Opportunities for microbial electrochemistry in municipal wastewater treatment - an overview
}

\author{
Oskar Modin $^{1 *}$, David J. I. Gustavsson ${ }^{2}$ \\ ${ }^{1}$ Division of Water Environment Technology, Department of Civil and Environmental Engineering, Chalmers \\ University of Technology, SE-412 96, Gothenburg, Sweden \\ (E-mail: oskar.modin@chalmers.se) \\ ${ }^{2}$ VA SYD, Box 191, SE-201 21 Malmö, Sweden \\ (E-mail: david.gustavsson@vasyd.se) \\ *Corresponding author: +46 317722138
}

\begin{abstract}
Microbial bioelectrochemical systems (BESs) utilise living microorganisms to drive oxidation and reduction reactions at solid electrodes. BESs could potentially be used at municipal wastewater treatment plants (WWTPs) to recover the energy content of organic matter, to produce chemicals useful at the site, or to monitor and control biological treatment processes. In this paper, we review bioelectrochemical technologies that could be applied for municipal wastewater treatment. Sjölunda WWTP in Malmö, Sweden, is used as an example to illustrate how the different technologies potentially could be integrated in an existing treatment plant and the impact they could have on the plant's utilization of energy and chemicals.
\end{abstract}

Keywords: Bioelectrochemical system; biogas; microbial electrolysis cell; microbial fuel cell; wastewater treatment

\section{INTRODUCTION}

Microbial bioelectrochemical systems (BESs) could potentially contribute to more sustainable treatment of municipal wastewater. In BESs, living microorganisms serve as catalysts for oxidation or reduction reactions on solid electrodes. This makes it possible to directly convert the chemical energy stored in dissolved organic matter in wastewater into electrical energy. However, production of electric power is only one of many possible applications. BESs could also be used for denitrification, generation of energy carriers and other valuable chemicals, or be used as sensors.

BESs can be classified as microbial fuel cells (MFCs), which generate electrical power, or microbial electrolysis cells (MECs), which consume electrical power to generate a valuable product. Examples of an MFC and an MEC are shown in Figure 1. Further details about the operating mechanisms of BESs can be found in several review papers (e.g. Logan et al. 2006; Rabaey et al. 2007; Rozendal et al. 2008b; Hamelers et al. 2009; Lefebvre et al. 2011; Pant et al. 2012). 


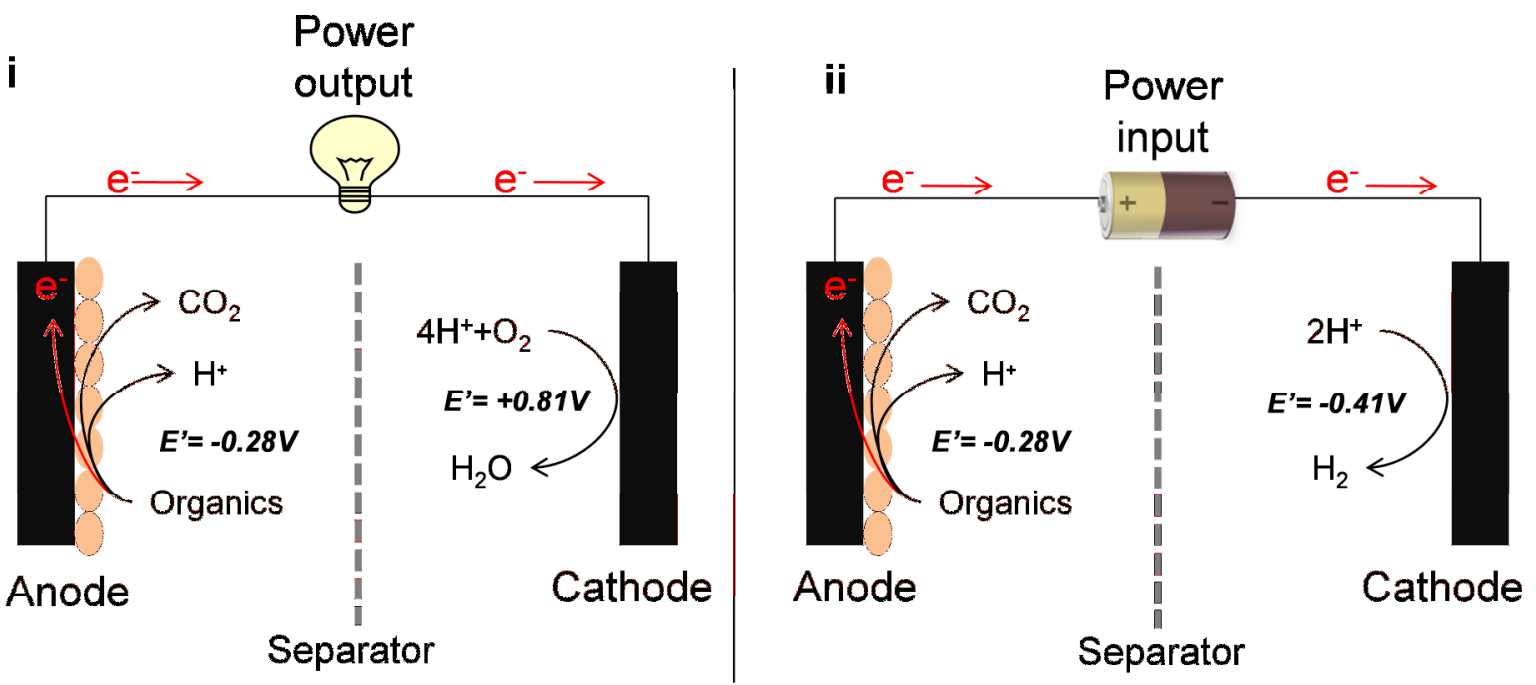

Figure 1. Examples of BESs illustrated by (i) an MFC generating electric power and (ii) an MEC generating hydrogen. E' represents the reduction potentials for the shown reactions at $\mathrm{pH} 7$ assuming the organics are acetate. Theoretically, the maximum voltage output from the MFC is $1.09 \mathrm{~V}$ and the minimum voltage input to the MEC is $0.13 \mathrm{~V}$.

BESs can be traced back to 1911 when it was noted that the microbial degradation of organic matter gave rise to an electromotive force in an electrochemical cell (Potter 1911). However, the discovery received relatively little attention during the $20^{\text {th }}$ century, partly because of the low power output (Schröder 2011). The interest in BESs resurged at the turn of the century when it was shown that microorganisms present in wastewater could oxidise organics and generate current without the addition of external electron transfer mediators (Kim et al. 2001). This discovery together with a rising interest in sustainable technologies for energy, fuel, and chemical production in a time of growing concern about peak oil (Murray \& King 2012) and global warming (Broecker 1975) has resulted in a tremendous increase in the number of scientific papers about BESs during the last ten years. However, today there are still no fullscale applications of BESs for municipal wastewater treatment. Thus far, the only well-known practical applications of BESs are the use of a benthic MFC to power a meteorological buoy (Tender et al. 2008), the use of MFCs to charge a cell phone (Ieropoulos et al. 2013), and the commercialization of an MFC-based sensor for biochemical oxygen demand (BOD) (http://korbi.en.ecplaza.net/). However, several start-up companies are trying to commercialize the technology (Pant et al. 2011).

For BESs to play a role in future municipal wastewater treatment plants (WWTPs), the technology must first be proven in existing plants. The goal of this paper is to review the different bioelectrochemical technologies that potentially could be integrated with an existing municipal WWTP. We use Sjölunda WWTP, located in Malmö in southern Sweden, as an example to illustrate how BESs could fit into the process solution of an existing plant.

\section{OVERVIEW OF BIOELECTROCHEMICAL TECHNOLOGIES}

\section{MFCs generating electric power}

Electric power generation using an MFC is the most studied BES application (Figure 1). Organic compounds are oxidized by microorganisms using the anode as electron acceptor. The electrons flow through an external circuit to the cathode where oxygen is reduced (Logan et al. 2006). Electrical energy can be recovered from the external circuit because the overall reaction, oxidation of organics and reduction of oxygen, is thermodynamically favourable. In 
theory, the maximum voltage that can be generated in one MFC is around $1.1 \mathrm{~V}$. In practice, the voltage will be lower because of internal losses such as activation overpotentials associated with the kinetics of electrode reaction, ohmic losses associated with electron transfer through wires and ion migration through the electrolyte, and concentration overpotentials associated with inefficient mass transfer of reagents and products near electrodes (Clauwaert et al. 2008a). Open circuit voltages as high as $0.8 \mathrm{~V}$ have been observed in an MFC operated with municipal wastewater (Ahn \& Logan 2010). The operating cell voltage corresponding to the maximum power output will, however, be lower; it was around $0.38 \mathrm{~V}$ in the study by Ahn and Logan (2010). To produce practically useful voltages $(\sim 12 \mathrm{~V})$, several MFCs have to be stacked in series which introduces additional challenges with voltage reversal in some cells (Aelterman et al. 2006b; Oh \& Logan 2007).

The highest power density generated by an MFC is $2080 \mathrm{~W} \mathrm{~m}^{-3}$, which was achieved in a well-designed $30-\mathrm{mL}$ reactor fed with a nutrient medium containing $100 \mathrm{mM}$ acetate and 100 $\mathrm{mM}$ phosphate buffer (Fan et al. 2012). In general, higher power densities have been observed with nutrient media containing phosphate buffer and e.g. acetate as carbon source than with real wastewater (Pant et al. 2010b). A summary of the performance of single-chamber MFCs operated with real municipal wastewater is shown in Table 1. It should be noted that most of the studies were performed at elevated temperatures.

Table 1. Performance of single-chamber MFCs for electricity production using pre-settled municipal wastewaters.

\begin{tabular}{|c|c|c|c|c|c|c|c|}
\hline $\begin{array}{l}\text { COD } \\
\text { influent } \\
\left(\mathrm{mg} \mathrm{L}^{-1}\right)\end{array}$ & $\begin{array}{l}\text { Temp. } \\
\left({ }^{\circ} \mathrm{C}\right)\end{array}$ & 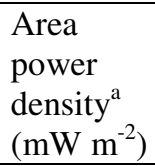 & $\begin{array}{l}\text { Volumetric } \\
\text { power } \\
\text { density } \\
\left(\mathrm{W} \mathrm{m}^{-3}\right)\end{array}$ & $\begin{array}{l}\text { Operating } \\
\text { voltage }(\mathrm{V})\end{array}$ & $\begin{array}{l}\text { COD } \\
\text { removal } \\
(\%)\end{array}$ & $\begin{array}{l}\mathrm{CE}^{\mathrm{b}} \\
(\%)\end{array}$ & Reference \\
\hline $210-220$ & 30 & 26 & 0.19 & 0.21 & $40-80$ & $3-12$ & (Liu et al. 2004) \\
\hline $200-300$ & 30 & 146 & 3.7 & 0.32 & 75 & 20 & $($ Liu \& Logan 2004) \\
\hline $200-300$ & 30 & 28 & 0.7 & 0.14 & 55 & 28 & $\left(\right.$ Liu \& Logan 2004) ${ }^{\mathrm{d}}$ \\
\hline 246 & 30 & $43-72$ & $10.8-18$ & $0.36-0.47$ & $42-79$ & $\sim 6$ & (Min \& Logan 2004) \\
\hline 300 & 25 & 103 & 5.8 & 0.25 & 71 & 18.4 & (You et al. 2006) \\
\hline 255 & 30 & 464 & 15.5 & 0.34 & $40-50$ & 27 & (Cheng et al. 2006) \\
\hline 345 & 23 & $207^{\mathrm{e}}$ & 5.2 & 0.38 & 83 & 18 & (Cusick et al. 2010) \\
\hline $440-490$ & 23 & $177^{\mathrm{e}}$ & 5.4 & 0.25 & 23 & 38 & (Ahn \& Logan 2010) \\
\hline $440-490$ & 30 & $170^{\mathrm{e}}$ & 5.2 & 0.25 & 33 & 26 & (Ahn \& Logan 2010) \\
\hline 671 & 22 & 42 & & 0.23 & 28 & 0.71 & (Nimje et al. 2012) \\
\hline 390 & 30 & 185 & 9.3 & 0.36 & 80 & 8.6 & (Hays et al. 2011) \\
\hline $232 \pm 84$ & 30 & $62-120^{\mathrm{e}}$ & $1.8-3.3$ & $0.30-0.35^{\mathrm{f}}$ & $>90$ & $15-22$ & (Ahn \& Logan 2012) \\
\hline $232 \pm 84$ & 30 & $19^{\mathrm{e}, \mathrm{f}}$ & $0.5^{\mathrm{f}}$ & $0.26^{\mathrm{f}}$ & 52 & $6^{\mathrm{f}}$ & (Ahn \& Logan 2012) \\
\hline
\end{tabular}

${ }^{\mathrm{a}}$ Based on anode surface area unless otherwise specified

${ }^{\mathrm{b}}$ Coulombic efficiency, i.e. efficiency with which organic matter is converted into electrical current

${ }^{c}$ Operated without a proton exchange membrane

${ }^{\mathrm{d} O p e r a t e d}$ with a proton exchange membrane

${ }^{\mathrm{e}}$ Based on cathode surface area

${ }^{\mathrm{f}}$ Calculated from data given in the article

\section{MFCs for denitrification}

Conventional enhanced nitrogen removal at municipal WWTPs is the two-step process of autotrophic nitrification and heterotrophic denitrification. Typically, organic compounds in the wastewater are used as electron donors for denitrification. However, at low carbon-tonitrogen ratios, dosage of external carbon source is needed. Autotrophic denitrifiers utilise inorganic sulphur or iron compounds, hydrogen, ammonia, or nitrite (Zumft 1997). Sakakibara and Kuroda (1993) used electrolysis to produce hydrogen for autotrophic denitrification. However, denitrifiers can also directly utilise a cathode as electron donor 
(Gregory et al. 2004). Clauwaert et al. (2007) demonstrated the concept of simultaneous anodic acetate oxidation and cathodic nitrate reduction from two separate liquid streams in an MFC. Virdis et al. (2008) used a single synthetic wastewater stream adding a separate nitrification step in the flow line between the anode and the cathode. However, ammonium diffusion from the anode compartment to the cathode compartment decreased nitrogen removal efficiency down to 67-70\%. Virdis et al. (2010) improved their concept by promoting simultaneous nitrification and denitrification in the cathode compartment and increased the nitrogen removal to $94 \%$. However, $29 \%$ of the nitrogen load was emitted as nitrous oxide $\left(\mathrm{N}_{2} \mathrm{O}\right)$ making the removal unsustainable because $\mathrm{N}_{2} \mathrm{O}$ is a very potent greenhouse gas $(\mathrm{GHG})$ with a global warming potential $\left(\mathrm{GWP}_{100}\right)$ of $296 \mathrm{~kg} \mathrm{CO}_{2 \mathrm{e}} \mathrm{kg}^{-1} \mathrm{~N}_{2} \mathrm{O}$ (Forster et al. 2007), and the carbon footprint of the WWTP will be multiplied several times (Gustavsson \& Tumlin 2013). Normal levels of $\mathrm{N}_{2} \mathrm{O}$ emissions are below $1 \%$ of the nitrogen load (Kampschreur et al. 2009). Virdis et al. (2009) showed that the $\mathrm{N}_{2} \mathrm{O}$ production could be minimised by decreasing cathodic potential in a system with a separate nitrification reactor. Xie et al. (2011) combined a regular MFC with a denitrifying MFC. Nitrification took place in the aerobic cathode of the MFC. The system removed $97.3 \%$ of the total nitrogen and produced power densities of 14 and $7.2 \mathrm{~W} / \mathrm{m}^{3}$ in the regular and denitrifying MFCs, respectively. Zhang and $\mathrm{He}$ (2012) built an MFC consisting of an aerobic and a denitrifying cathode compartment connected to the same anode. All the studies cited above were conducted with various nutrient media prepared in the laboratory. Zhang et al. (2013) operated 4-L MFCs with real primary settled wastewater for over 400 days. They achieved 65-70\% COD removal at 11-h hydraulic retention time. When a denitrifying MFC was connected, the total nitrogen removal reached $76 \%$. Energy balances considering the energy requirements for pumping were positive for the MFCs operated without nitrogen removal with an output of $19 \mathrm{Wh} \mathrm{kg}^{-1} \mathrm{COD}$. With denitrification, the net energy balance was negative with a consumption of $53 \mathrm{Wh} \mathrm{kg}^{-1} \mathrm{COD}$.

Except for the risk of high $\mathrm{N}_{2} \mathrm{O}$ emissions, nitrogen removal in an MFC has several positive aspects compared to conventional nitrogen removal: no large-volume recycling streams are required for pre-denitrification, electricity can be produced, no organic carbon is required for denitrification, and low biomass production due to autotrophic denitrification. As shown in the review above, various reactor configurations have been developed for denitrifying MFCs; however, few have been tested with real municipal wastewater.

\section{MECs for production of energy carriers}

\section{Hydrogen}

In an MEC, the energy content of dissolved organic matter can be recovered as hydrogen (Liu et al. 2005; Rozendal et al. 2006a; Logan et al. 2008). The operational principle is similar to an MFC. However, the cathode is kept anaerobic, which allows hydrogen ions to be reduced to hydrogen gas. The overall reaction, i.e. oxidation of organics and reduction of hydrogen ions, is thermodynamically unfavourable, which means that a voltage input is necessary to drive the reactions. In theory, a voltage of at least $0.13 \mathrm{~V}$ is required (Figure 1). In practice, an input voltage of at least $0.2 \mathrm{~V}$ will be needed (Call \& Logan 2008). Compared to MFCs, MECs do not need a supply of oxygen to the cathode, which facilitates construction. On the other hand, a system to collect and process the produced gas is needed. Because MECs are operated with anaerobic cathode compartment, diffusion of oxygen into the anode compartment can be avoided and higher coulombic efficiencies are obtained (Cusick et al. 2010), which means that a larger fraction of the removed organic matter is used to generate current in the system. 
Several studies have explored MECs for hydrogen production with nutrient medium containing acetate as feed to the biological anode. Such systems have achieved high energy efficiencies (i.e. energy content in the produced hydrogen relative to the input of electrical energy) of up to $406 \%$ (Call \& Logan 2008). A few studies have been carried out with real wastewater (Ditzig et al. 2007; Cusick et al. 2010; Escapa et al. 2012; Heidrich et al. 2013). Cusick et al. (2010) used carbon fiber brush anode and Pt-catalyzed cathode in a $28 \mathrm{~mL}$ reactor operated at a cell voltage of $0.9 \mathrm{~V}$. They achieved an energy efficiency of $104 \%$ and a $\mathrm{H}_{2}$ production rate of $0.28 \mathrm{~m}^{3} \mathrm{~m}^{-3} \mathrm{~d}^{-1}$. They also directly compared lab-scale MFC and MEC operation for energy recovery from municipal wastewater. Although the energy recovery was higher with the MFC ( $0.22 \mathrm{vs} 0.14 \mathrm{kWh} \mathrm{kg}^{-1} \mathrm{COD}$ for the MEC), the monetary value was higher for the MEC because of the high price of hydrogen compared to electricity (MEC: 0.19 $\$ \mathrm{~kg}^{-1}$ COD, MFC: $0.021 \$ \mathrm{~kg}^{-1} \mathrm{COD}$ ) (Cusick et al. 2010). Both Escapa et al. (2012) and Ditzig et al. (2007) investigated various input voltages in mL-scale MECs and achieved good performance at $0.5 \mathrm{~V}$. Heidrich et al. (2013) constructed a 120-L pilot-scale reactor containing electrode cassettes with carbon-felt anodes and stainless steel cathodes. The domestic wastewater fed to the reactor had a temperature of $13.5-21.0^{\circ} \mathrm{C}$ during the study period. The reactor was mostly run at an input voltage of $1.1 \mathrm{~V}$. Pure $\mathrm{H}_{2}$ gas was produced at $0.015 \mathrm{~m}^{3} \mathrm{H}_{2}$ $\mathrm{m}^{-3} \mathrm{~d}^{-1}$ and $70 \%$ of the electrical energy input needed to run the reactor was recovered as $\mathrm{H}_{2}$ gas. The net energy requirement for COD removal was $2.3 \mathrm{~kJ} \mathrm{~kg}^{-1} \mathrm{COD}$, which is comparable to typical values for activated sludge.

\section{Methane}

In MECs designed for hydrogen production, methane will often also be produced by hydrogenotrophic methanogens (Clauwaert \& Verstraete 2009). This is usually considered a nuisance and different strategies have been employed to avoid methane formation (Wang et al. 2009); for example, periodic exposure of the reactor to air (Call \& Logan 2008) or removing bicarbonate from the liquid medium (Rozendal et al. 2008a). However, MECs can also be designed to generate methane gas (Clauwaert et al. 2008b). It has been suggested that an MEC could improve combustion properties of biogas by mixing in some hydrogen (Aelterman et al. 2006a), which however may not be advisable if the biogas is upgraded to natural gas quality and sent to the natural gas pipe system since hydrogen-containing gas has different safety regulations. Although methane has a $20 \%$ lower energy value than hydrogen, many WWTPs currently have an infrastructure in place to valorize methane. Methane can be generated on the cathode indirectly via hydrogen or directly by biocatalysis (Cheng et al. 2009; Villano et al. 2010). There are no reports on methane MECs operated with municipal wastewater. However, in some wastewater-fed MEC designed for hydrogen production, methane has been a major constituent of the produced gas. In the first pilot-scale MEC trial, a $1 \mathrm{~m}^{3}$ reactor containing graphite fiber brush anodes and stainless steel mesh cathode was used to treat winery wastewater. During the startup of the reactor, gas production was low $\left(0.09 \mathrm{~m}^{3}\right.$ $\mathrm{m}^{-3} \mathrm{~d}^{-1}$ ) and contained $33 \% \mathrm{H}_{2}$. After increasing the temperature of the reactor to $31^{\circ} \mathrm{C}$ and adding acetic acid, the gas production increased up to $0.28 \mathrm{~m}^{3} \mathrm{~m}^{-3} \mathrm{~d}^{-1}$; however, in this latter phase of the experiment the methane content of the gas was $86 \%$ and hydrogen was not detected. Most of the biogas production was not associated with current, but was produced directly from organic compounds in the wastewater (Cusick et al. 2011).

Anaerobic digestion is often used at WWTPs for treatment of waste sludge and BESs could potentially be used to stimulate the activities of digesters. Sasaki et al. (2011) placed the cathode of a BES into an anaerobic digester and observed improved methane production and COD removal, as well as a higher ratio of methanogens to total prokaryotes suspended in the reactors. Guo et al. (2013) integrated both the anode and cathode with the anaerobic digester 
and observed hydrogen production followed by improved methane production in the bioelectrochemically stimulated digesters compared to controls. By anodic oxidation of volatile fatty acids in the reactor, the $\mathrm{pH}$ could be maintained at a higher level and hydrogen generated at the cathode could be further converted into methane by hydrogenotrophic methanogens (Guo et al. 2013).

\section{BESs for production of chemicals}

\section{Production and onsite utilization of alkali}

In BESs, it is common to use cation exchange membranes (CEM) to separate the anode and cathode compartments. CEMs contain negatively charged groups fixed to the polymer matrix, which allow the transfer of cations through the membrane but exclude anions. When CEMs are used in BESs, transport of cations such as $\mathrm{Na}^{+}, \mathrm{K}^{+}, \mathrm{NH}_{4}{ }^{+}, \mathrm{Ca}^{2+}$ and $\mathrm{Mg}^{2+}$ often dominate due to their high concentrations in wastewater (Rozendal et al. 2006b). This leads to a $\mathrm{pH}$ decrease (alkalinity consumption) in the anode compartment due to the acidifying oxidation of organics and a $\mathrm{pH}$ increase (alkalinity production) in the cathode compartment due to proton consumption by e.g. oxygen reduction to water or proton reduction to hydrogen gas. In MFCs this is usually considered a problem; however, the phenomenon could also be utilised to harvest an alkaline solution in the cathode chamber (Rabaey et al. 2010). An important aspect of this application is that the flow rate through the anode chamber must be much larger than the flow rate through the cathode chamber to avoid the development of a low anode $\mathrm{pH}$ that could negatively affect the biological activity. Rabaey et al. (2010) operated an MEC with fixed anode potential and acetate as electron donor at the anode. The system generated up to $1015 \mathrm{~A} \mathrm{~m}^{-3}$ anode volume, and produced an alkaline solution corresponding to $3.4 \mathrm{wt} \%$ $\mathrm{NaOH}$ at an energy input of $1.06 \mathrm{kWh} \mathrm{kg}^{-1} \mathrm{NaOH}$. When wastewater from a brewery was used as anode feed, currents up to $367 \mathrm{~A} \mathrm{~m}^{-3}$ were achieved and the alkali production was significantly lower.

Instead of producing a concentrated alkali, a BES could be used to redistribute alkalinity between process streams in a WWTP. Sludge liquor produced from the anaerobic digestion of sludge contains high ammonium concentration, which is often nitrified before being fed back into the treatment plant. Nitrification consumes alkalinity, which must be added, e.g. in the form of $\mathrm{NaOH}$. Since the influent wastewater flow is much larger than the sludge liquor flow, alkalinity could be redistributed from the influent wastewater without a large change in concentration, to the sludge liquor where it could support nitrification. Modin et al. (2011) demonstrated this concept using synthetic wastewater and sludge liquor. The same concept can also be used to strip ammonia from sludge liquor and recover it in acid. In a study using real sludge liquor as catholyte, up to $79 \%$ of the ammonia could be recovered. Hydrogen generation was achieved simultaneously (Wu \& Modin 2013).

\section{Production of hydrogen peroxide}

Hydrogen peroxide $\left(\mathrm{H}_{2} \mathrm{O}_{2}\right)$ can be produced in the cathode of BESs by oxygen reduction (Rozendal et al. 2009). The reduction of $\mathrm{O}_{2}$ to $\mathrm{H}_{2} \mathrm{O}_{2}$ has a standard reduction potential of 0.28 $\mathrm{V}$ at $\mathrm{pH}$ 7. This means that an MFC can drive the production of $\mathrm{H}_{2} \mathrm{O}_{2}$ without an external input of electrical power (Modin \& Fukushi 2012). However, higher production rates can be achieved by applying a voltage. Rozendal et al. (2009) used an acetate-containing nutrient medium as anolyte and produced a $0.13 \mathrm{wt} \% \mathrm{H}_{2} \mathrm{O}_{2}$ solution in the cathode chamber at an applied voltage of $0.5 \mathrm{~V}$, which meant an energy input of $0.93 \mathrm{kWh} \mathrm{kg}^{-1} \mathrm{H}_{2} \mathrm{O}_{2}$. Modin and Fukushi (2012) also used an acetate-containing nutrient medium as anolyte and produced a $\mathrm{H}_{2} \mathrm{O}_{2}$ concentration of $0.5 \%$ with an energy consumption of $1.77 \mathrm{kWh} \mathrm{kg}^{-1} \mathrm{H}_{2} \mathrm{O}_{2}$. When they 
switched anolyte to raw municipal wastewater, the current in the system dropped to about $20 \%$ of the value with acetate medium, and the produced $\mathrm{H}_{2} \mathrm{O}_{2}$ concentration was only $0.01 \%$ (Modin \& Fukushi 2012). In a reactor with larger anode, a concentration exceeding $0.2 \%$ could be produced at an energy cost of $8.3 \mathrm{kWh} \mathrm{kg}^{-1} \mathrm{H}_{2} \mathrm{O}_{2}$ with real municipal wastewater as anode feed (Modin \& Fukushi 2013). The studies cited above used gas-diffusion cathodes catalysed by carbon nanoparticles. Lower concentrations were produced using graphite rods submerged in the liquid (Fu et al. 2010). Fenton's reagent, which is a strong oxidant consisting of $\mathrm{H}_{2} \mathrm{O}_{2}$ and an iron catalyst, was generated in-situ in an MFC with an ironcontaining cathode (Feng et al. 2010).

\section{Reduction of $\mathrm{CO}_{2}$}

One of the most recent topics in BES research is microbial electrosynthesis (MES). This refers to the reduction of carbon dioxide by cathodic microorganisms to produce organic compounds (Centi \& Perathoner 2009; Nevin et al. 2010). Abiotic electrochemical reduction of carbon dioxide has not proven practical, and using living microorganisms as cathode catalysts could be a way forward (Nevin et al. 2010). The anaerobic digester at a WWTP produces a fairly concentrated stream of carbon dioxide that potentially could be upgraded to a valuable chemical product. Cheng et al. (2009) reported that methanogenic microorganisms were capable of carbon dioxide reduction to methane using a cathode as direct electron donor. Villano et al. (2010) observed that methane was produced both by abiotically produced hydrogen via hydrogenotrophic methanogenesis and via direct extracellular electron transfer. Nevin et al. (2011) demonstrated that several acetogenic microorganisms can reduce carbon dioxide to acetate and other multicarbon compounds using a cathode as electron donor. A mixture of acetate, methane, and hydrogen was produced by a mixed microbial community enriched on a cathode (Marshall et al. 2012). Other chemicals that potentially could be produced include ethanol (Steinbush et al. 2010) and caproate (Van Eerten-Jansen et al. 2013).

\section{Microbial electrochemical sensors}

Biochemical oxygen demand (BOD) is an important parameter in WWTPs. It is a measure of the amount of biodegradable organics in wastewater and is used to dimension and assess treatment processes. The conventional method to measure BOD takes 5-7 days and requires skilled personnel. In WWTPs, the activated sludge process is used to remove dissolved organic material. Aeration of activated sludge represents a major energy cost, so optimization of this process is desirable for WWTPs. Because of the lack of reliable online sensors for BOD concentration, other parameters such as dissolved oxygen, water flow, total suspended solids, and air flow rates are used to control the activated sludge process (Hedegärd \& Wik 2011).

The MFC has emerged as an alternative to the conventional BOD test. In an MFC, microbes convert organic compounds directly into an electrical current, which is easy to measure. Thus, MFCs have been suggested as online sensors for BOD concentration (Kim et al. 2003a).

Several types of MFC-based BOD sensors have been investigated. The correlation parameter (i.e. the parameter that is measured and correlated to BOD concentration) is either current (i.e. voltage over a resistor) or charge (i.e. coulombs transferred through a circuit for a specified time interval). In cases when the current is correlated with BOD concentration, the wastewater is fed continuously though the anode chamber of the MFC and the current is measured as the voltage across a resistor (e.g. Moon et al. 2004). In cases when charge is correlated with BOD concentration, the wastewater is fed batchwise to the anode chamber and the charge is calculated by integrating the current over a specific time interval (e.g. Kim et al. 2003a) 
A summary of the MFC-based BOD sensors described in the literature is provided in Table 2. In most cases the measurable concentration range is up to a few hundred $\mathrm{mg} \mathrm{L}^{-1}$ and the response time ranges from a few minutes to several hours. The response time for a downshift step in concentration is usually longer than an upshift concentration change (Moon et al. 2004; Di Lorenzo et al. 2009a; Di Lorenzo et al. 2009b).

Table 2. MFC-based BOD sensors described in the literature.

\begin{tabular}{|c|c|c|c|}
\hline $\begin{array}{l}\text { Correlation } \\
\text { parameter }\end{array}$ & Concentration range & Response time & Reference \\
\hline Charge & $<206 \mathrm{mg} \mathrm{L}^{-1}$ & $\begin{array}{l}30 \mathrm{~min}(6.45 \mathrm{ppm}), \\
10 \mathrm{~h}(206.4 \mathrm{ppm})\end{array}$ & (Kim et al. 2003a) \\
\hline Charge & $80-150 \mathrm{mg} \mathrm{L}^{-1}$ & $45 \mathrm{~min}$ & (Kim et al. 2003b) \\
\hline Current & $<100 \mathrm{~m} \mathrm{mg} \mathrm{L}^{-1}$ & $60 \mathrm{~min}$ & (Chang et al. 2004) \\
\hline Current & Tested $50 \& 100 \mathrm{mg} \mathrm{L}^{-1}$ & $\begin{array}{l}5 \min \text { (upshift) } \\
11 \text { min (downshift) }\end{array}$ & (Moon et al. 2004) \\
\hline Current & $2-10 \mathrm{mg} \mathrm{L}^{-1}$ & $60 \min$ & (Moon et al. 2005) \\
\hline Charge & $50-200 \mathrm{mg} \mathrm{L}^{-1}$ & $1 \mathrm{~h}$ & (Kim et al. 2009) \\
\hline Current & $\begin{array}{l}25-25,000 \mathrm{mg} \mathrm{L}^{-1} \\
\text { glucose }\end{array}$ & $3-5 \min$ & (Kumlanghan et al. 2007) \\
\hline Current & $<350 \mathrm{mg} \mathrm{L}^{-1}$ & 40 min (upshift) & (Di Lorenzo et al. 2009a) \\
\hline Charge & $<500 \mathrm{mg} \mathrm{L}^{-1}$ & $2 \mathrm{~h}$ (downshift) & \\
\hline Current & Tested $70 \& 250 \mathrm{mg} \mathrm{L}^{-1}$ & $\begin{array}{l}3.5 \mathrm{~h} \text { (upshift) } \\
14 \mathrm{~h} \text { (downshift) }\end{array}$ & (Di Lorenzo et al. 2009b) \\
\hline Current & $17-78 \mathrm{mg} \mathrm{L}^{-1}$ & $\begin{array}{l}30 \mathrm{~min}(\text { at } 17 \mathrm{mg} \\
\left.\mathrm{L}^{-1}\right) \\
10 \mathrm{~h}\left(\text { at } 78 \mathrm{mg} \mathrm{L}^{-1}\right)\end{array}$ & (Peixoto et al. 2011) \\
\hline Charge & $32-1280 \mathrm{mg} \mathrm{L}^{-1}$ & $5-20 \mathrm{~h}$ & (Modin \& Wilén 2012) \\
\hline
\end{tabular}

MFCs have also been investigated as toxicity sensors. Kim et al. (2007) investigated how organophosphorous compounds, $\mathrm{Pb}, \mathrm{Hg}$, and $\mathrm{PCBs}$ affected the electric current generation in an MFC. The additions of these compounds to the influent to the MFC inhibited current output. Patil et al. (2010) compared biofilm-based MFCs and planktonic cell MFCs as toxicity sensor. They found that planktonic cell were much more sensitive to toxic shocks and therefore more suitable as toxicity sensor. MFCs could also be used for real-time monitoring of anaerobic digesters. Liu et al. (2011) placed an MFC in an aerobic digester and monitored how the current was correlated with other parameters in the digester.

\section{Other applications}

BES could potentially play a role in phosphorous recovery at WWTPs. By utilizing the localized $\mathrm{pH}$ increased at the cathode, struvite could be obtained in a hydrogen-producing MEC (Cusick \& Logan 2012). Fisher et al. (2011) used an MFC to mobilize phosphate from $\mathrm{FePO}_{4}$ in sewage sludge for subsequent recovery as struvite.

BESs could also be a way of integrating municipal wastewater treatment with other processes such as desalination and solid waste management. By placing alternating anion- and cation exchange membranes between the anode and cathode in an MFC, water desalination can be accomplished in the central compartments (Cao et al. 2009). Such a system could be used as pre-treatment for a reverse osmosis process (Mehanna et al. 2010). BESs could recover metals such as copper on the cathode (Ter Heijne et al. 2010; Tao et al. 2011). Municipal solid waste 
incineration fly ash contains high concentrations of various metals such as copper and zinc. The metals can be leached out from the ashes using acids. The dissolved organics in presettled municipal wastewater could be used to power electrolytic recovery of the metals from the leachate solutions (Modin et al. 2012).

\section{INTEGRATING BESs INTO A WWTP}

The primary goal of WWTPs is to treat wastewater to certain discharge limits. This can already be achieved with currently available technologies. Bioelectrochemical technologies could potentially contribute by reducing the net energy- or chemical consumption, or by providing better technology for monitoring processes at the plants. However, applying BESs at full-scale WWTPs is not trivial. Scale-up from the mostly laboratory-scale systems that have been investigated to date is an important issue. Moreover, we must consider which of the possible technologies will make the biggest contribution to a treatment plant, in terms of e.g. reduced energy or chemical consumption, at an acceptable cost.

\section{Scale-up issues}

Scaling up BESs is challenging and lower performance with larger reactors has been observed (Dewan et al. 2008). Issues related to scale up include cost of reactor materials, conductivity of electrodes and wastewater, performance in stacked cells, current densities with real wastewater, and stability of electrochemically active biofilms.

- Cost of reactor materials: Often materials used in laboratory-scale setups, e.g. carbon cloth and platinum-catalysed electrodes, are too expensive for full-scale wastewater application. However, alternatives exist and several researchers have investigated inexpensive electrode materials, catalysts, membranes, and current collectors (see e.g. Logan 2010; Pant et al. 2010a).

- Conductivity: Municipal wastewater has low conductivity compared to the nutrient solutions that have been used in most laboratory studies. This means that anode and cathode must be placed very close to each other to minimize ohmic losses related to ion migration. For example, at a wastewater conductivity of $1 \mathrm{mS} \mathrm{cm}^{-1}$ and a current density of $10 \mathrm{~A} \mathrm{~m}^{-2}$, the ohmic losses would be $1 \mathrm{~V}$ per $\mathrm{cm}$ distance between anode and cathode. Furthermore, carbon materials, which are often used as electrodes, are 400-500 times less electrically conductive than copper and resistive losses can be high as electrodes as scaled-up. To solve conductivity issues related to scale-up, anode and cathode could be pressed against opposite sides of ion-conductive membranes and current collectors made of e.g. stainless steel could be integrated with carbon electrode materials.

- Stacked cell performance: Full-scale BESs would consist of many smaller reactors connected in parallel or in series. For example, stacks of MFCs electrically connected in series would be required to achieve practically useful output voltages. Because of certain variability in the capacity for current generation by individuals reactors in the stack, this could lead to voltage reversal in some reactors and long-term inactivation of the microbes (Oh \& Logan 2007). This problem could be solved using various types of control circuits (Kim et al. 2011; Andersen et al. 2013). It is likely also beneficial to try to ensure that all reactors in a stack have the same hydraulic conditions and are fed with wastewater containing the same concentration of organic substrate.

- Current density: The highest current densities in BESs have been obtained with wellbuffered nutrient media containing high concentrations of acetate (e.g. Fan et al. 2012). It is still unclear what current densities can be obtained with real municipal wastewater. The current density is an important parameter as it determines the required size of reactor. 
- Stability of biofilm: Full-scale BESs should be operated for long time with stable performance. Research indicates that long-term ( $>5$ years) stable performance of electrochemically active biofilms is possible (Kim et al. 2003a). However, further research on how electrochemically active communities respond over time to the varying conditions in municipal wastewater is needed.

\section{Perspectives - using Sjölunda WWTP as an example}

Sjölunda WWTP is used as an example to illustrate the possible impact of different BESs (details of the theoretical calculations carried out in this section are shown in the supplementary material). The plant has an average load of about 300,000 population equivalents (P.E.) $\left(1\right.$ P.E. $=70 \mathrm{~g} \mathrm{BOD}_{7}$ person $^{-1}$ day $\left.^{-1}\right)$ and its process layout is shown in Figure 2 (Hanner et al. 2003). The discharge limits for $\mathrm{BOD}_{7}$, nitrogen and phosphorus are currently $12 \mathrm{mg} \mathrm{L}^{-1}$ (monthly average), $10 \mathrm{mg} \mathrm{L}^{-1}$ (yearly average) and $0.3 \mathrm{mg} \mathrm{L}^{-1}$ (monthly average), respectively. The electrical energy consumption at the plant is approximately 50 MWh d ${ }^{-1}$, about 2,184 ton COD of carbon source is dosed annually to the post-denitrification reactor (mostly methanol), and about 900 ton $\mathrm{yr}^{-1}$ of $50 \% \mathrm{NaOH}$ is added to the sludge liquor nitritation reactor.

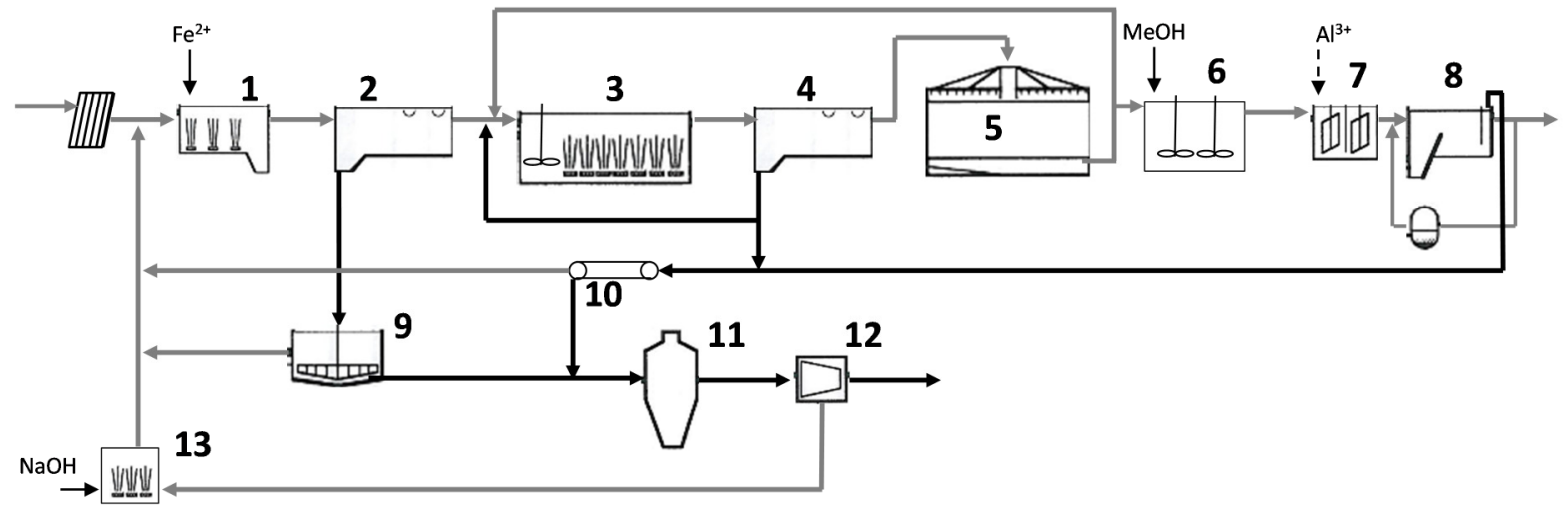

Figure 2. Simplified process layout for Sjölunda WWTP. The main stream is treated by (1) ferrous sulphate dosage for phosphorous precipitation, (2) pre-settler, (3) activated sludge with pre-denitrification, (4) secondary settler, (5) nitrifying trickling filters, (6) post-denitrification in moving bed biofilm reactors, (7) alum dosage and (8) flotation for removal of suspended solids. The sludge is thickened in a gravity thickener (9) or gravity belt thickener (10) and treated by mesophilic anaerobic digestion (11). The digested sludge is centrifuged (12) and the sludge liquor is treated in a separate nitritation reactor with $\mathrm{NaOH}$ dosing (13) before being fed back into the main treatment stages.

There are two process streams containing dissolved organic matter that potentially could be used as anode feed in BESs. The pre-settled wastewater has COD load of $40144 \mathrm{~kg} \mathrm{~d}^{-1}$, which represents approximately $198 \mathrm{MWh} \mathrm{d}^{-1}$ assuming an energy content of $17.8 \mathrm{~kJ} \mathrm{~g}^{-1} \mathrm{COD}$ (Heidrich et al. 2011). This is four times the current energy consumption at the plant. The other process stream of interest is the sludge liquor which contains $47.1 \mathrm{~kg}^{\mathrm{COD} \mathrm{d}} \mathrm{d}^{-1}$ as volatile fatty acids (VFAs). Although VFAs are ideal substrates for BES anodes, this stream only contains an energy content representing less than $0.5 \%$ of the total energy consumption at the plant. Therefore, to have a significant impact on the energy-efficiency of the plant, BESs should target the pre-settled wastewater. Currently, $2344 \mathrm{~kg} \mathrm{COD} \mathrm{d}^{-1}$ in the pre-settled wastewater is used for denitrification of nitrate recycled from the trickling filters and nitrite from the reject water nitritation reactor. This leaves $37800 \mathrm{~kg} \mathrm{COD} \mathrm{d}^{-1}$ to be oxidized aerobically in the activated sludge at an energy cost of about $0.4 \mathrm{kWh} \mathrm{kg}^{-1} \mathrm{COD}$ (Fig. 2, process 3). If $80 \%$ of this COD load could instead be utilized in BESs, the electrical energy savings in reduced aeration requirements would be about $12.0 \mathrm{MWh} \mathrm{d}^{-1}$, which represents $24 \%$ of the plant's total consumption. 
If the COD load currently being oxidized aerobically instead was utilised to generate electrical energy in MFCs at 20\% energetic efficiency, $22.3 \mathrm{MWh} \mathrm{d}^{-1}$ could be produced. Together with the savings in reduced aeration of activated sludge tanks, this means a total reduction in electrical energy consumption by $69 \%$ at Sjölunda WWTP.

The COD load could also be used to generate $\mathrm{H}_{2}$ or $\mathrm{CH}_{4}$. Since Sjölunda, like many other WWTPs, already is capable of valorizing methane gas, it may be advisable to initially focus on producing methane rather than hydrogen. Theoretically, $80 \%$ of the available pre-settled COD load could generate over 4 million $\mathrm{Nm}^{3} \mathrm{yr}^{-1}$ of methane gas which would more than double the current production ( 3.3 million $\mathrm{Nm}^{3} \mathrm{yr}^{-1}$ ). The biogas presently generated contains about $1,924,000 \mathrm{Nm}^{3} \mathrm{yr}^{-1}$ of $\mathrm{CO}_{2}$. Upgrading this to $\mathrm{CH}_{4}$ in a MEC would only require $38 \%$ of the available COD load in the pre-settled wastewater. The electrical energy requirements to power MECs would be substantial. At an operating voltage $0.5 \mathrm{~V}$, the additional electrical energy input required to bioelectrochemically convert $80 \%$ of the pre-settled COD load into $\mathrm{CH}_{4}$ would be $38.7 \mathrm{MWh} \mathrm{d}^{-1}$, which would increase the present energy consumption by $77 \%$.

If MFCs for denitrification were implemented at Sjölunda WWTP, the existing trickling filter could be utilized for nitrification. The activated sludge tanks and the post-denitrification tank (processes 3 and 6 in Fig. 2) could be replaced with a MFC system. To denitrify the total load of nitrate from the trickling filters and nitrite from reject water nitritation reactor, $7633 \mathrm{~kg}$ $\mathrm{COD} \mathrm{d}^{-1}$ would be required. Since, the total COD load from the pre-settlers is $40,144 \mathrm{~kg} \mathrm{~d}^{-1}$ aerobic MFCs could be operated in addition to the denitrifying MFC. Over 2,000 ton COD of carbon source currently used for post-denitrification could be saved every year.

The pre-settled wastewater could also be used to generate alkali or $\mathrm{H}_{2} \mathrm{O}_{2}$. The value and market for the produced products are difficult to predict because they will probably not have the same purity as commercially available products. However, both alkali and $\mathrm{H}_{2} \mathrm{O}_{2}$ could be used onsite at WWTPs and thereby replace presently used chemicals. In these BESs, ion exchange membranes would be used to separate the anode and cathode compartments and alkalinity concentration in the wastewater, rather than COD concentration, would limit the amount of chemical product that could be produced. Sjölunda's pre-settled wastewater has an alkalinity load of $593 \mathrm{keq} \mathrm{d}^{-1}$ of which $329 \mathrm{keq} \mathrm{d}^{-1}$ are needed to support nitrification in the trickling filters. This leaves $264 \mathrm{keq} \mathrm{d}^{-1}$, which theoretically could be consumed in the production of concentrated alkali or $\mathrm{H}_{2} \mathrm{O}_{2}$. Sjölunda WWTP uses 462 ton $\mathrm{yr}^{-1}$ of $100 \% \mathrm{NaOH}$ to control the $\mathrm{pH}$ of the nitritation reactor treating sludge liquor. This could be generated onsite by extraction from the pre-settled wastewater. Only $32 \mathrm{keq} \mathrm{d}^{-1}$, or $12 \%$ of the available load, would be needed to support the onsite demand. Another option would be to use onsite generated alkali to strip and recover ammonia from the sludge liquor (e.g. Wu \& Modin 2013). $\mathrm{H}_{2} \mathrm{O}_{2}$ is currently not used at Sjölunda WWTP. However, if the plant was converted to a membrane bioreactor plant, e.g. to meet more stringent effluent requirements in the future, onsite generated $\mathrm{H}_{2} \mathrm{O}_{2}$ could be used for membrane cleaning. Assuming a daily maintenance backwash with $0.2 \% \mathrm{H}_{2} \mathrm{O}_{2}$ and a backwash water to treated water volume ratio of 0.004 (Modin et al. 2010), $832 \mathrm{~kg} \mathrm{H}_{2} \mathrm{O}_{2} \mathrm{~d}^{-1}$ would have to be generated. This corresponds to $49 \mathrm{keq}$ $\mathrm{d}^{-1}$ of alkalinity consumption in the pre-settled wastewater, which is $19 \%$ of the available load, or $392 \mathrm{~kg} \mathrm{COD} \mathrm{d}^{-1}$, which is only $1 \%$ of the available COD load.

BES-based sensors could be used to provide more information about the state and characteristics of treatment processes at Sjölunda WWTP. BOD sensors could give near realtime measurements of the concentrations of biodegradable organics going into and coming 
out from the activated sludge process. BOD sensors could also be applied after the postdenitrification process as an extra warning system for excess carbon dosage. Sensors placed in the anaerobic digester could provide information on the VFA content of the sludge liquor.

These sensors could be used as indicators of the digester's response to new feeds, for example if the treatment plant decides to accept new industrial or agricultural organic waste in addition to the sludge. Bioelectrochemical toxicity sensors could be used as warning systems upstream from the treatment plant to show whether wastewater with hostile characteristics, e.g. low $\mathrm{pH}$, is on its way to the plant.

A comparison of the reviewed technologies is shown in Table 3. The magnitudes of the required current for application at Sjölunda give an estimation of the size of the different systems relative to each other. Although the exact size of BESs for full-scale applications are difficult to estimate based on the mostly laboratory-scale studies presented in the literature, it is clear that the MFC, MEC for $\mathrm{CH}_{4}$, and denitrifying MFC processes will all be large systems. In comparison, BESs operated to fulfil onsite needs of alkali or $\mathrm{H}_{2} \mathrm{O}_{2}$ would be relatively small. The larger systems would potentially produce large economic savings for the treatment plant by reducing electricity consumption, increasing methane output, or eliminating the need for external carbon source (Table 3). However, the capital costs would also be higher.

The capital costs of BESs are difficult to estimate. However, based on the value of the generated products and savings in electricity and chemical consumption, maximum allowed capital costs per unit ampere to achieve a payback period of less than 10 years were calculated. For example, $3.3 € \mathrm{~A}^{-1}$ for MFCs means that for a MFC system installed at Sjölunda WWTP to have a payback period of less than 10 years, the capital cost may not be larger than $3.3 €$ per installed unit ampere (assumptions used in these calculations are described in the supplementary materials). The MFC, MEC for $\mathrm{CH}_{4}$, and denitrifying MFC processes have low allowed capital costs of 1.5-6.0€ $\mathrm{A}^{-1}$. This is because of the low value of the produced products (electricity, methane, or methanol carbon source saved). BESs for alkali or $\mathrm{H}_{2} \mathrm{O}_{2}$ production have higher allowed capital costs because of the higher value of the products. The calculation was not carried out for bioelectrochemical sensors because they are assumed to have negligible size and cost compared to the other processes. The capital cost per unit ampere of a system would depend on the cost of the materials used and the current density obtained. In MFC systems the current density can be increased by decreasing the internal resistance whereas in MEC systems, the current density can be increased more easily, simply by increasing the applied voltage. Therefore, MEC systems may be closer to practical application (Sleutels et al. 2012). However, increased current densities would also increase internal losses and lead to higher operational costs.

It should be noted that more studies with pilot-scale reactors are needed to perform an accurate comparison of the economic and environmental benefits of different bioelectrochemical technologies at a full scale WWTP. However, the analysis in Table 3 suggests that implementing bioelectrochemical sensors or systems for covering onsite chemical needs would represent a smaller capital investment and possibly a shorter payback period. Thus, these systems potentially represent shorter paths of development towards fullscale application at WWTPs. Full-scale application of a bioelectrochemical technology at a WWTP would be an important step in the development of other BESs as well. 
Table 3. Comparison of different bioelectrochemical technologies for application at Sjölunda WWTP (assumption used the calculations are described in the supplementary material).

\begin{tabular}{|c|c|c|c|}
\hline Process & $\mathbf{I}(\mathbf{k A})$ & $\begin{array}{l}\text { Allowed capital cost for a } 10 \\
\text { year payback period }\left(€ A^{-1}\right)\end{array}$ & Impact on the plant \\
\hline MFC & 4221 & 2.4 & $\begin{array}{l}\text { Reduced electric power consumption by } \\
69 \% \text {, economic savings of } 1001 \mathrm{k}^{-1} \mathrm{yr}^{-1}\end{array}$ \\
\hline $\begin{array}{l}\mathrm{MEC} \text { for } \\
\mathrm{CH}_{4}\end{array}$ & 4221 & 1.5 & $\begin{array}{l}125 \% \text { increase in } \mathrm{CH}_{4} \text { output, } 77 \% \text { increase } \\
\text { in electric power, net economic savings of } \\
634{\mathrm{k€} \mathrm{yr}^{-1}}^{-1}\end{array}$ \\
\hline $\begin{array}{l}\text { Denitrifying } \\
\text { MFC }\end{array}$ & 1065 & 6.0 & $\begin{array}{l}2184 \text { ton COD carbon source saved, } \\
\text { economic savings of } 634 \mathrm{k}^{-1} \mathrm{yr}^{-1}\end{array}$ \\
\hline $\begin{array}{l}\text { BES for } \\
\text { alkali }\end{array}$ & 35.3 & 50.3 & $\begin{array}{l}900 \text { ton of } 50 \% \mathrm{NaOH} \text { saved, economic } \\
\text { savings of } 178{\mathrm{k€} \mathrm{yr}^{-1}}^{-1}\end{array}$ \\
\hline $\begin{array}{l}\text { BES for } \\
\mathrm{H}_{2} \mathrm{O}_{2}\end{array}$ & 54.7 & 60.9 & $\begin{array}{l}\text { Useful if MBR plant and the } \mathrm{H}_{2} \mathrm{O}_{2} \text { can be } \\
\text { utilized onsite for membrane cleaning }\end{array}$ \\
\hline Sensors & $\sim 0$ & & $\begin{array}{l}\text { Better opportunities for monitoring and } \\
\text { control of treatment processes }\end{array}$ \\
\hline
\end{tabular}

\section{CONCLUSIONS}

During the last decade, researchers have developed several bioelectrochemical technologies that potentially could be applied at WWTPs. MFCs and MECs could contribute to the energy efficiency of the plants by producing electric power or energy carriers from the organic content of pre-settled wastewater. Denitrifying MFCs could potentially contribute to energyefficiency and also eliminate the need to add external carbon sources. BESs could produce alkali and $\mathrm{H}_{2} \mathrm{O}_{2}$, two useful chemicals at WWTPs, onsite. Bioelectrochemical sensors could improve the opportunities for monitoring and control of treatment processes. Although there are many opportunities for BESs at WWTPs, full-scale applications are still lacking. An analysis of the process flows at Sjölunda WWTP suggests that full-scale applications of bioelectrochemical sensors or BES for covering onsite chemical needs would need to deliver a significantly lower electrical current in comparison with MFCs and MECs for producing energy carriers. The former applications would therefore likely be smaller, have lower capital cost and higher value of produced products, and development of these may therefore represent a shorter path to demonstrate bioelectrochemical technology at full-scale in WWTPs.

\section{Acknowledgements}

O.M. was funded by the Swedish Research Council (VR, projects 2010-612 and 2012-5167) and a Marie Curie Career Integration Grant (bioanode).

\section{References}

Aelterman P., Rabaey K., Clauwaert P. and Verstraete W. (2006a). Microbial fuel cells for wastewater treatment. Water Science \& Technology 54(8), 9-15.

Aelterman P., Rabaey K., Pham H. T., Boon N. and Verstraete W. (2006b). Continuous electricity generation at high voltages and currents using stacked microbial fuel cells. Environmental Science \& Technology 40(10), 3388-94.

Ahn Y. and Logan B. E. (2010). Effectiveness of domestic wastewater treatment using microbial fuel cells at ambient and mesophilic temperatures. Bioresource Technology 101(2), 469-75.

Ahn Y. and Logan B. E. (2012). Domestic wastewater treatment using multi-electrode continuous flow MFCs with a separator electrode assembly design. Applied Microbiology \& Biotechnology 97(1), 40916.

Andersen S. J., Pikaar I., Freguia S., Lovell B. C., Rabaey K. and Rozendal R. A. (2013). Dynamically adaptive control system for bioanodes in serially stacked bioelectrochemical systems. Environmental Science \& Technology 47(10), 5488-94.

Broecker W. S. (1975). Climatic change: are we on the brink of a pronounced global warming? Science 
189(4201), 460-3.

Call D. and Logan B. E. (2008). Hydrogen production in a single chamber microbial electrolysis cell lacking a membrane. Environmental Science \& Technology 42(9), 3401-6.

Cao X., Huang X., Liang P., Xiao K., Zhou Y., Zhang X. and Logan B. (2009). A new method for water desalination using microbial desalination cells. Environmental Science \& Technology 43(18), 7148-52.

Centi G. and Perathoner S. (2009). Opportunities and prospects in the chemical recycling of carbon dioxide to fuels. Catalysis Today 148(3-4), 191-205.

Chang I. S., Jang J. K., Gil G. C., Kim M., Kim H. J., Cho B. W. and Kim B. H. (2004). Continuous determination of biochemical oxygen demand using microbial fuel cell type biosensor. Biosensors \& Bioelectronics 19(6), 607-13.

Cheng S., Liu H. and Logan B. E. (2006). Increased power generation in a continuous flow MFC with advective flow through the porous anode and reduced electrode spacing. Environmental Science \& Technology 40(7), 2426-32.

Cheng S., Xing D., Call D. F. and Logan B. E. (2009). Direct biological conversion of electrical current into methane electromethanogenesis. Environmental Science \& Technology 43(10), 3953-8.

Clauwaert P., Aelterman P., Pham T. H., De Schamphelaire L., Carballa M., Rabaey K. and Verstraete W. (2008a). Minimizing losses in bio-electrochemical systems: the road to applications. Applied Microbiology \& Biotechnology 79(6), 901-13.

Clauwaert P., Rabaey K., Aelterman P., de Schamphelaire L., Pham T. H., Boeckx P., Boon N. and Verstraete W. (2007). Biological denitrification in microbial fuel cells. Environmental Science \& Technology 41(9), 3354-60.

Clauwaert P., Tolêdo R., van der Ha D., Crab R., Verstraete W., Hu H., Udert K. M. and Rabaey K. (2008b). Combining biocatalyzed electrolysis with anaerobic digestion. Water Science \& Technology 57(4), 575-9.

Clauwaert P. and Verstraete W. (2009). Methanogenesis in membraneless microbial electrolysis cells. Applied Microbiology and Biotechnology 82(5), 829-36.

Cusick R. D., Bryan B., Parker D. S., Merrill M. D., Mehanna M., Kiely P. D., Liu G. and Logan B. E. (2011). Performance of a pilot-scale continuous flow microbial electrolysis cell fed winery wastewater. Applied Microbiology \& Biotechnology 89(6), 2053-63.

Cusick R. D., Kiely P. D. and Logan B. E. (2010). A monetary comparison of energy recovered from microbial fuel cells and microbial electrolysis cells fed winery or domestic wastewaters. International Journal of Hydrogen Energy 35(17), 8855-61.

Cusick R. D. and Logan B. E. (2012). Phosphate recovery as struvite within a single chamber microbial electrolysis cell. Bioresource Technology 107, 110-5.

Dewan A., Beyenal H. and Lewandowski Z. (2008). Scaling up microbial fuel cells. Environmental Science \& Technology 42(20), 7643-8.

Di Lorenzo M., Curtis T. P., Head I. M. and Scott K. (2009a). A single-chamber microbial fuel cell as a biosensor for wastewaters. Water Research 43(13), 3145-54.

Di Lorenzo M., Curtis T. P., Head I. M., Velasquez-Orta S. B. and Scott K. (2009b). A single chamber packed bed microbial fuel cell biosensor for measuring organic content of wastewater. Water Science \& Technology 60(11), 2879-87.

Ditzig J., Liu H. and Logan B. (2007). Production of hydrogen from domestic wastewater using a bioelectrochemically assisted microbial reactor (BEAMR). International Journal of Hydrogen Energy 32(13), 2296-304.

Escapa A., Gil-Carrera L., García V. and Morán A. (2012). Performance of a continuous flow microbial electrolysis cell (MEC) fed with domestic wastewater. Bioresource Technology 117, 55-62.

Fan Y., Han S.-K. and Liu H. (2012). Improved performance of CEA microbial fuel cells with increased reactor size. Energy \& Environmental Science 5(8), 8273-80.

Feng C.-H., Li F.-B., Mai H.-J. and Li X.-Z. (2010). Bio-electro-Fenton process driven by microbial fuel cell for wastewater treatment. Environmental Science \& Technology 44(5), 1875-80.

Fischer F., Bastian C., Happe M., Mabillard E. and Schmidt N. (2011). Microbial fuel cell enables phosphate recovery from digested sewage sludge as struvite. Bioresource Technology 102(10), 5824-30.

Forster P., Ramaswamy V., Artaxo P., Berntsen T., Betts R., Fahey D. W., Haywood J., Lean J., Lowe D. C., Myhre G., Nganga J., Prinn R., Raga G., Schulz M. and Van Dorland R. (2007). Changes in Atmospheric Constituents and in Radiative Forcing, Press CU, Cambridge.

Fu L., You S.-J., Yang F.-1., Gao M.-m., Fang X.-h. and Zhang G.-q. (2010). Synthesis of hydrogen peroxide in microbial fuel cell. Journal of Chemical Technology \& Biotechnology 85(5), 715-9.

Gregory K. B., Bond D. R. and Lovley D. R. (2004). Graphite electrodes as electron donors for anaerobic respiration. Environmental Microbiology 6(6), 596-604. 
Guo X., Liu J. and Xiao B. (2013). Bioelectrochemical enhancement of hydrogen and methane production from the anaerobic digestion of sewage sludge in single-chamber membrane-free microbial electrolysis cells. International Journal of Hydrogen Energy 38(3), 1342-7.

Gustavsson D. J. I. and Tumlin S. (2013). Carbon footprint of Scandinavian wastewater treatment plants. Water Science \& Technology 68(4), 887-93.

Hamelers H. V. M., Heijne A., Sleutels T. H. J. A., Jeremiasse A. W., Strik D. P. B. T. B. and Buisman C. J. N. (2009). New applications and performance of bioelectrochemical systems. Applied Microbiology \& Biotechnology 85(6), 1673-85.

Hanner N., Aspegren H., Nyberg U. and Andersson B. (2003). Upgrading the Sjölunda WWTP according to a novel process concept. Water Science \& Technology 47(12), 1-7.

Hays S., Zhang F. and Logan B. E. (2011). Performance of two different types of anodes in membrane electrode assembly microbial fuel cells for power generation from domestic wastewater. Journal of Power Sources 196(20), 8293-300.

Hedegärd M. and Wik T. (2011). An online method for estimation of degradable substrate and biomass in an aerated activated sludge process. Water Research 45(19), 6308-20.

Heidrich E. S., Curtis T. P. and Dolfing J. (2011). Determination of the Internal Chemical Energy of Wastewater. Environmental Science \& Technology 45(2), 827-32.

Heidrich E. S., Dolfing J., Scott K., Edwards S. R., Jones C. and Curtis T. P. (2013). Production of hydrogen from domestic wastewater in a pilot-scale microbial electrolysis cell. Applied Microbiology and Biotechnology 97(15), 6979-89.

Ieropoulos I. A., Ledezma P., Stinchcombe A., Papaharalabos G., Melhuish C. and Greenman J. (2013). Waste to real energy: the first MFC powered mobile phone. Phys Chem Chem Phys 15(37), 15312-6.

Kampschreur M. J., Temminck H., Kleerebezem R., Jetten M. S. M. and van Loosdrecht M. C. M. (2009). Nitrous oxide emission during wastewater treatment. Water Research 43(17), 4093-103.

Kim B., Chang I., Hyun M., Kim H. and Park H. (2001). A biofuel cell using wastewater and activated sludge for wastewater treatment. In, International Patent WO 01/04061 A1.

Kim B. H., Chang I. S., Gil G. C., Park H. S. and Kim H. J. (2003a). Novel BOD (biological oxygen demand) sensor using mediator-less microbial fuel cell. Biotechnology Letters 25(7), 541-5.

Kim M., Hyun M. S., Gadd G. M., Kim G. T., Lee S. J. and Kim H. J. (2009). Membrane-electrode assembly enhances performance of a microbial fuel cell type biological oxygen demand sensor. Environmental Technology 30(4), 329-36.

Kim M., Sik Hyun M., Gadd G. M. and Joo Kim H. (2007). A novel biomonitoring system using microbial fuel cells. Journal of Environmental Monitoring 9(12), 1323.

Kim M., Youn S. M., Shin S. H., Jang J. G., Han S. H., Hyun M. S., Gadd G. M. and Kim H. J. (2003b). Practical field application of a novel BOD monitoring system. Journal of Environmental Monitoring 5(4), 640-3.

Kim Y., Hatzell M. C., Hutchinson A. J. and Logan B. E. (2011). Capturing power at higher voltages from arrays of microbial fuel cells without voltage reversal. Energy \& Environmental Science 4(11), 4662-7.

Kumlanghan A., Liu J., Thavarungkul P., Kanatharana P. and Mattiasson B. (2007). Microbial fuel cell-based biosensor for fast analysis of biodegradable organic matter. Biosensors and Bioelectronics 22(12), 2939-44.

Lefebvre O., Uzabiaga A., Chang I. S., Kim B.-H. and Ng H. Y. (2011). Microbial fuel cells for energy selfsufficient domestic wastewater treatment-a review and discussion from energetic consideration. Applied Microbiology \& Biotechnology 89(2), 259-70.

Liu H., Grot S. and Logan B. E. (2005). Electrochemically assisted microbial production of hydrogen from acetate. Environmental Science \& Technology 39(11), 4317-20.

Liu H. and Logan B. E. (2004). Electricity generation using an air-cathode single chamber microbial fuel cell in the presence and absence of a proton exchange membrane. Environmental Science \& Technology 38, 4040-6.

Liu H., Ramnarayanan R. and Logan B. E. (2004). Production of electricity during wastewater treatment using a single chamber microbial fuel cell. Environmental Science \& Technology 38(7), 2281-5.

Liu Z., Liu J., Zhang S., Xing X.-H. and Su Z. (2011). Microbial fuel cell based biosensor for in situ monitoring of anaerobic digestion process. Bioresource Technology 102(22), 10221-9.

Logan B. E. (2010). Scaling up microbial fuel cells and other bioelectrochemical systems. Applied Microbiology and Biotechnology 85(6), 1665-71.

Logan B. E., Call D., Cheng S., Hamelers H. V. M., Sleutels T. H. J. A., Jeremiasse A. W. and Rozendal R. A. (2008). Microbial electrolysis cells for high yield hydrogen gas production from organic matter. Environmental Science \& Technology 42(23), 8630-40.

Logan B. E., Hamelers B., Rozendal R., Schröder U., Keller J., Freguia S., Aelterman P., Verstraete W. and Rabaey K. (2006). Microbial fuel cells: methodology and technology. Environmental Science \& 
Technology 40(17), 5181-92.

Marshall C. W., Ross D. E., Fichot E. B., Norman R. S. and May H. D. (2012). Electrosynthesis of commodity chemicals by an autotrophic microbial community. Applied and Environmental Microbiology 78(23), 8412-20.

Mehanna M., Saito T., Yan J., Hickner M., Cao X., Huang X. and Logan B. E. (2010). Using microbial desalination cells to reduce water salinity prior to reverse osmosis. Energy \& Environmental Science 3(8), 1114-20.

Min B. and Logan B. E. (2004). Continuous electricity generation from domestic wastewater and organic substrates in a flat plate microbial fuel cell. Environmental Science \& Technology 38(21), 580914.

Modin O. and Fukushi K. (2012). Development and testing of bioelectrochemical reactors converting wastewater organics into hydrogen peroxide. Water Science \& Technology 66(4), 831-6.

Modin O. and Fukushi K. (2013). Production of high concentrations of H2O2 in a bioelectrochemical reactor fed with real municipal wastewater. Environmental Technology 34(19), 2737-42.

Modin O., Fukushi K., Rabaey K., Rozendal R. and Yamamoto K. (2010). Bioelectrochemical hydrogen peroxide production - an opportunity for sustainable mitigation of membrane bioreactor fouling. In: WEF/IWA Biofilm Reactor Technologies Conference, Portland, Oregon, USA, pp. 449-61.

Modin O., Fukushi K., Rabaey K., Rozendal R. A. and Yamamoto K. (2011). Redistribution of wastewater alkalinity with a microbial fuel cell to support nitrification of reject water. Water Research 45(8), 2691-9.

Modin O., Wang X., Wu X., Rauch S. and Fedje K. K. (2012). Bioelectrochemical recovery of Cu, Pb, Cd, and Zn from dilute solutions. Journal of Hazardous Materials 235-236, 291-7.

Modin O. and Wilén B.-M. (2012). A novel bioelectrochemical BOD sensor operating with voltage input. Water Research 46(18), 6113-20.

Moon H., Chang I. S., Jang J. K., Kim K. S., Lee J., Lovitt R. W. and Kim B. H. (2005). On-line monitoring of low biochemical oxygen demand through continuous operation of a mediator-less microbial fuel cell. Journal of Microbiology and Biotechnology 15(1), 192-6.

Moon H., Chang I. S., Kang K. H., Jang J. K. and Kim B. H. (2004). Improving the dynamic response of a mediator-less microbial fuel cell as a biochemical oxygen demand sensor. Biotechnology Letters 26(22), 1717-21.

Murray J. and King D. (2012). Climate policy: oil's tipping point has passed. Nature 481(7382), 433-5.

Nevin K. P., Hensley S. A., Franks A. E., Summers Z. M., Ou J., Woodard T. L., Snoeyenbos-West O. L. and Lovley D. R. (2011). Electrosynthesis of Organic Compounds from Carbon Dioxide Is Catalyzed by a Diversity of Acetogenic Microorganisms. Applied \& Environmental Microbiology 77(9), 2882-6.

Nevin K. P., Woodard T. L., Franks A. E., Summers Z. M. and Lovley D. R. (2010). Microbial electrosynthesis: Feeding microbes electricity to convert carbon dioxide and water to multicarbon extracellular organic compounds. mBio 1(2), e00103-10-e-10.

Nimje V. R., Chen C.-Y., Chen H.-R., Chen C.-C., Huang Y. M., Tseng M.-J., Cheng K.-C. and Chang Y.-F. (2012). Comparative bioelectricity production from various wastewaters in microbial fuel cells using mixed cultures and a pure strain of Shewanella oneidensis. Bioresource Technology 104, 315-23.

Oh S. E. and Logan B. E. (2007). Voltage reversal during microbial fuel cell stack operation. Journal of Power Sources 167(1), 11-7.

Pant D., Singh A., Van Bogaert G., Gallego Y. A., Diels L. and Vanbroekhoven K. (2011). An introduction to the life cycle assessment (LCA) of bioelectrochemical systems (BES) for sustainable energy and product generation: Relevance and key aspects. Renewable and Sustainable Energy Reviews 15(2), 1305-13.

Pant D., Singh A., Van Bogaert G., Irving Olsen S., Singh Nigam P., Diels L. and Vanbroekhoven K. (2012). Bioelectrochemical systems (BES) for sustainable energy production and product recovery from organic wastes and industrial wastewaters. RSC Advances 2(4), 1248-63.

Pant D., Van Bogaert G., De Smet M., Diels L. and Vanbroekhoven K. (2010a). Use of novel permeable membrane and air cathodes in acetate microbial fuel cells. Electrochimica Acta 55(26), 7710-6.

Pant D., Van Bogaert G., Diels L. and Vanbroekhoven K. (2010b). A review of the substrates used in microbial fuel cells (MFCs) for sustainable energy production. Bioresource Technology 101(6), 1533-43.

Patil S., Harnisch F. and Schröder U. (2010). Toxicity response of electroactive microbial biofilms - a decisive feature for potential biosensor and power source applications. ChemPhysChem 11(13), 2834-7.

Peixoto L., Min B., Martins G., Brito A. G., Kroff P., Parpot P., Angelidaki I. and Nogueira R. (2011). In situ microbial fuel cell-based biosensor for organic carbon. Bioelectrochemistry 81(2), 99-103.

Potter M. C. (1911). Electrical Effects Accompanying the Decomposition of Organic Compounds. Proceedings 
of the Royal Society B: Biological Sciences 84(571), 260-76.

Rabaey K., Butzer S., Brown S., Keller J. and Rozendal R. A. (2010). High current generation coupled to caustic production using a lamellar bioelectrochemical system. Environmental Science \& Technology 44(11), 4315-21.

Rabaey K., Rodríguez J., Blackall L. L., Keller J., Gross P., Batstone D., Verstraete W. and Nealson K. H. (2007). Microbial ecology meets electrochemistry: electricity-driven and driving communities. The ISME Journal 1(1), 9-18.

Rozendal R., Hamelers H., Euverink G., Metz S. and Buisman C. (2006a). Principle and perspectives of hydrogen production through biocatalyzed electrolysis. International Journal of Hydrogen Energy 31(12), 1632-40.

Rozendal R., Jeremiasse A. W., Hamelers H. V. M. and Buisman C. J. N. (2008a). Hydrogen production with a microbial biocathode. Environmental Science \& Technology 42(2), 629-34.

Rozendal R. A., Hamelers H. V. M. and Buisman C. J. N. (2006b). Effects of membrane cation transport on pH and microbial fuel cell performance. Environmental Science \& Technology 40, 5206-11.

Rozendal R. A., Hamelers H. V. M., Rabaey K., Keller J. and Buisman C. J. N. (2008b). Towards practical implementation of bioelectrochemical wastewater treatment. Trends in Biotechnology 26(8), 450-9.

Rozendal R. A., Leone E., Keller J. and Rabaey K. (2009). Efficient hydrogen peroxide generation from organic matter in a bioelectrochemical system. Electrochemistry Communications 11(9), 1752-5.

Sakakibara Y. and Kuroda M. (1993). Electric prompting and control of denitrification. Biotechnology and Bioengineering 42(4), 535-7.

Sasaki K., Morita M., Sasaki D., Hirano S., Matsumoto N., Watanabe A., Ohmura N. and Igarashi Y. (2011). A bioelectrochemical reactor containing carbon fiber textiles enables efficient methane fermentation from garbage slurry. Bioresource Technology 102(13), 6837-42.

Schröder U. (2011). Discover the possibilities: microbial bioelectrochemical systems and the revival of a 100year-old discovery. Journal of Solid State Electrochemistry 15(7-8), 1481-6.

Sleutels T. H., Ter Heijne A., Buisman C. J. and Hamelers H. V. (2012). Bioelectrochemical systems: an outlook for practical applications. ChemSusChem 5(6), 1012-9.

Steinbush K. J. J., Hamelers H. V. M., Schaap J. D., Kampman C. and Buisman C. (2010). Bioelectrochemical ethanol production through mediated acetate reduction by mixed cultures. Environmental Science \& Technology 44(1), 513-7.

Tao H. C., Liang M., Li W., Zhang L. J., Ni J. R. and Wu W. M. (2011). Removal of copper from aqueous solution by electrodeposition in cathode chamber of microbial fuel cell. Journal of Hazardous Materials 189(1-2), 186-92.

Tender L. M., Gray S. A., Groveman E., Lowy D. A., Kauffman P., Melhado J., Tyce R. C., Flynn D., Petrecca R. and Dobarro J. (2008). The first demonstration of a microbial fuel cell as a viable power supply: Powering a meteorological buoy. Journal of Power Sources 179(2), 571-5.

Ter Heijne A., Liu F., van der Weijden R., Weijma J., Buisman C. J. N. and Hamelers H. V. M. (2010). Copper reduction combined with electricity production in a microbial fuel cell. Environmental Science \& Technology 44(11), 4376-81.

Van Eerten-Jansen M. C. A. A., Ter Heijne A., Grootscholten T. I. M., Steinbusch K. J. J., Sleutels T. H. J. A., Hamelers H. V. M. and Buisman C. J. N. (2013). Bioelectrochemical Production of Caproate and Caprylate from Acetate by Mixed Cultures. ACS Sustainable Chemistry \& Engineering 1(5), 513-8.

Wang A., Liu W., Cheng S., Xing D., Zhou J. and Logan B. E. (2009). Source of methane and methods to control its formation in single chamber microbial electrolysis cells. International Journal of Hydrogen Energy 34(9), 3653-8.

Villano M., Aulenta F., Ciucci C., Ferri T., Giuliano A. and Majone M. (2010). Bioelectrochemical reduction of $\mathrm{CO} 2$ to $\mathrm{CH} 4$ via direct and indirect extracellular electron transfer by a hydrogenophilic methanogenic culture. Bioresource Technology 101(9), 3085-90.

Virdis B., Rabaey K., Rozendal R. A., Yuan Z. and Keller J. (2010). Simultaneous nitrification, denitrification and carbon removal in microbial fuel cells. Water Research 44(9), 2970-80.

Virdis B., Rabaey K., Yuan Z. and Keller J. (2008). Microbial fuel cells for simultaneous carbon and nitrogen removal. Water Research 42(12), 3013-24.

Virdis B., Rabaey K., Yuan Z., Rozendal R. A. and Keller J. (2009). Electron fluxes in a microbial fuel cell performing carbon and nitrogen removal. Environmental Science \& Technology 43(13), 5144-9.

Wu X. and Modin O. (2013). Ammonium recovery from reject water combined with hydrogen production in a bioelectrochemical reactor. Bioresource Technology, DOI: 10.1016/j.biortech.2013.07.130.

Xie S., Liang P., Chen Y., Xia X. and Huang X. (2011). Simultaneous carbon and nitrogen removal using an oxic/anoxic-biocathode microbial fuel cells coupled system. Bioresource Technology 102(1), 
348-54.

You S. J., Zhao Q. L., Jiang J. Q. and Zhang J. N. (2006). Treatment of domestic wastewater with simultaneous electricity generation in microbial fuel cell under continuous operation. Chemical and Biochemical Engineering Quarterly 20(4), 407-12.

Zhang F., Ge Z., Grimaud J., Hurst J. and He Z. (2013). Long-term performance of liter-scale microbial fuel cells treating primary effluent installed in a municipal wastewater treatment facility. Environmental Science \& Technology 47(9), 4941-8.

Zhang F. and He Z. (2012). Integrated organic and nitrogen removal with electricity generation in a tubular dualcathode microbial fuel cell. Process Biochemistry 47(12), 2146-51.

Zumft W. G. (1997). Cell biology and molecular basis of denitrification. Microbiology and Molecular Biology Reviews 61(4), 533-616. 


\title{
Supplementary material
}

\section{Opportunities for microbial electrochemistry in municipal wastewater treatment - an overview}

\author{
Oskar Modin and David J. I. Gustavsson
}

\section{Integrating BESs into a WWTP: Theoretical calculations using Sjölunda WWTP as an example}

\section{MFCs for generation of electric power}

Assuming $80 \%$ of the pre-settled COD load presently oxidized aerobically is used for current generation.

$37800 \mathrm{kgCOD} \mathrm{d}^{-1} \times 0.8 \times 0.4 \mathrm{kWh} \mathrm{kg}^{-1} \mathrm{COD}=11981 \mathrm{kWh} \mathrm{d}^{-1}$

Energy saved by reduced aeration $=12.0 \mathrm{MWh}^{-1}$

$37800 \mathrm{kgCOD} \mathrm{d}^{-1} \times 0.8 \times 1000 \mathrm{~g} \mathrm{~kg}^{-1} \times\left(8 \mathrm{gCOD} \mathrm{mol}^{-1} \mathrm{e}^{-1}\right)^{-1} \mathrm{x} 96485.3 \mathrm{C} \mathrm{mol}^{-1} \mathrm{e}^{-} \times\left(86400 \mathrm{~s} \mathrm{~d}^{-1}\right)^{-1}=$ $=4221278 \mathrm{C} / \mathrm{s}$

Current generated by the MFCs $=4221 \mathrm{kA}$

Assuming $1.1 \mathrm{~V}$ is the maximum theoretical output of a MFC and that they are operating at $20 \%$ energetic efficiency.

$4221278 \mathrm{~A}$ x $1.1 \mathrm{~V}$ x $0.2 \times 24 \mathrm{~h} \mathrm{~d}^{-1} \times\left(1000 \mathrm{~W} \mathrm{~kW}^{-1}\right)^{-1}=22288 \mathrm{kWh} \mathrm{d}^{-1}$

Power generated by the MFCs $=22.3 \mathrm{MWh}^{-1}$

Total electrical energy savings at the plant $=12.0+22.3=34.3 \mathrm{MWh}^{-1}$

At present, the electrical energy consumption at the plant is $49.9 \mathrm{MWh} \mathrm{d}^{-1}$.

Reduction in electrical energy consumption by introducing MFCs $=100 \%$ x 34.3/49.4 $=69 \%$

Assuming the price of electricity is $0.08 € \mathrm{kWh}-1$ (Eurostat 2013).

$34.3 \mathrm{MWh} \mathrm{d}^{-1}$ x $365 \mathrm{~d} \mathrm{yr}^{-1}$ x $1000 \mathrm{~kW} \mathrm{MW}^{-1}$ x $0.08 € \mathrm{kWh}^{-1}=1000659 € \mathrm{yr}^{-1}$

Economic savings $=1000.7{\mathrm{k} € \mathrm{yr}^{-1}}^{-1}$

Assuming zero interest rate in the calculation of payback period.

$1000659 € \mathrm{yr}^{-1} \times 10 \mathrm{yr} \times(4221278 \mathrm{~A})^{-1}=2.37 € \mathrm{~A}^{-1}$

Maximum allowed capital cost for 10-year payback period $=2.37 € A^{-1}$

MEC for methane production

Again, assuming $80 \%$ of the pre-settled COD is used for current generation.

Energy saved by reduced aeration $=12.0 \mathrm{MWh}^{-1}$

Current generated by the MECs $=4221 \mathrm{kA}$

Assuming voltage input to the MECs is $0.5 \mathrm{~V}$.

$0.5 \mathrm{~V} \mathrm{x} 4221278 \mathrm{~A} \times 24 \mathrm{~h} \mathrm{~d}^{-1}\left(1000 \mathrm{~W} \mathrm{~kW}^{-1}\right)^{-1}=50655 \mathrm{kWh} \mathrm{d}^{-1}$

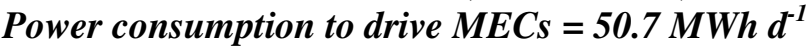


Overall increase in electric power consumption $=50.7-12.0=38.7 \mathrm{MWh}^{-1}$

Percentage increase $=100 \% \times 38.7 / 49.9=77 \%$

Assuming methane is produced from current at $100 \%$ efficiency.

$4221278 \mathrm{C} \mathrm{s}^{-1} \times 86400 \mathrm{~s} \mathrm{~d}^{-1} \times\left(96485.3 \mathrm{C} \mathrm{mol}^{-1} \mathrm{e}^{-1} \times\left(8 \mathrm{~mol} \mathrm{e}^{-} \mathrm{mol}^{-1} \mathrm{CH}_{4}\right)^{-1}=472505 \mathrm{molCH}_{4} \mathrm{~d}^{-1}\right.$

$472505 \times 23.6 \mathrm{~L} \mathrm{~mol}^{-1} \times 365 \mathrm{~d} \mathrm{yr}^{-1} \times\left(1000 \mathrm{~L} \mathrm{~m}^{-3}\right)^{-1}=4078671 \mathrm{~m}^{3} \mathrm{CH}_{4} \mathrm{yr}^{-1}$

Amount methane produced by $\mathrm{MECs}=4078671 \mathrm{~m}^{3} \mathrm{CH}_{4} \mathrm{yr}^{-1}$

Increase in plant's methane output $=100 \% \times 4078671 / 3276000=125 \%$

Assuming the value of methane is $0.046 € \mathrm{kWh}^{-1}$ (Eurostat 2013) and the energy content of methane is $0.2222 \mathrm{kWh} \mathrm{mol}^{-1}$.

$\left(472505 \mathrm{molCH}_{4} \mathrm{~d}^{-1} \times 0.2222 \mathrm{kWh} \mathrm{mol}^{-1} \times 0.046 € \mathrm{kWh}^{-1}-38700 \mathrm{kWh} \mathrm{d}^{-1} \times 0.08 € \mathrm{kWh}^{-1}\right)$

Economic savings $=633.6 \mathrm{k€yr^{-1 }}$

$$
\mathrm{x} 365 \mathrm{~d} \mathrm{yr}^{-1}=633673 € \mathrm{yr}^{-1}
$$

Assuming zero interest rate in the calculation of payback period.

$633673 € \mathrm{yr}^{-1} \mathrm{x} 10 \mathrm{yr} \times(4221278 \mathrm{~A})^{-1}=1.50 € \mathrm{~A}^{-1}$

Maximum allowed capital cost for 10-year payback period $=1.50 € \mathrm{~A}^{-1}$

\section{MFC for denitrification}

Assuming $100 \%$ utilization of the produced current for denitrification.

$\left(2301 \mathrm{kgNO}_{3}-\mathrm{N} \mathrm{d}^{-1} \times 5 \mathrm{~mol} \mathrm{e} \mathrm{mol}^{-1} \mathrm{NO}_{3}^{-}+617 \mathrm{kgNO}_{2}-\mathrm{N} \mathrm{d}^{-1} \times 3 \mathrm{~mol} \mathrm{e}^{-} \mathrm{mol}^{-1} \mathrm{NO}_{2}^{-}\right) \times\left(86400 \mathrm{~s} \mathrm{~d}^{-1}\right)^{-1} \mathrm{x}$ $96485.3 \mathrm{C} \mathrm{mol}^{-1} \mathrm{e}^{-} \times 1000 \mathrm{~g} \mathrm{~kg}^{-1} \times\left(14 \mathrm{~g} \mathrm{~mol}^{-1} \mathrm{~N}\right)^{-1}=1065481 \mathrm{C} \mathrm{s}^{-1}$

Current required to denitrify total $\mathrm{NO}_{2}^{-}$and $\mathrm{NO}_{3}^{-}$loads $=1065 \mathrm{kA}$

COD oxidation at anode

$7633 \mathrm{kgCOD} \bar{d}^{-1}$

$$
=1065481 \times 86400 \mathrm{~s} \mathrm{~d}^{-1} \times\left(96485.3 \mathrm{C} \mathrm{mol}^{-1} \mathrm{e}^{-}\right)^{-1} \times 8 \mathrm{gCOD} \mathrm{mol}^{-1} \mathrm{e}^{-} \times\left(1000 \mathrm{~g} \mathrm{~kg}^{-1}\right)^{-1}=
$$

Energy saved by reduced aeration $=0.40 \times 7633=3024 \mathrm{kWh}^{-1}$

Assuming the cost of methanol is $0.25 € \mathrm{~kg}^{-1} \mathrm{COD}$ and that the amount of methanol carbon source saved at the plant would be 2184 tonCOD $\mathrm{yr}^{-1}$.

$2184 \times 1000 \times 0.25+3024 \mathrm{kWh} \mathrm{d}^{-1} \times 365 \mathrm{~d} \mathrm{yr}^{-1} \times 0.08 € \mathrm{kWh}^{-1}=634302 € \mathrm{yr}^{-1}$

Economic savings $=634.3 \mathrm{k} € \mathrm{yr}^{-1}$

Assuming zero interest rate in the calculation of payback period.

$634302 € \mathrm{yr}^{-1} \times 10 \mathrm{yr} \times(1065481 \mathrm{~A})^{-1}=5.95 € \mathrm{~A}^{-1}$

Maximum allowed capital cost for 10-year payback period $=5.95 € A^{-1}$

\section{MEC for producing alkali}

Assuming 462 ton $\mathrm{yr}^{-1}$ of $100 \% \mathrm{NaOH}$ is needed at the plant and that alkalinity can be produced at the cathode of a MEC with $100 \%$ current efficiency.

462 tonNaOH yr${ }^{-1} \times 1000000 \mathrm{~g} \mathrm{ton}^{-1} \times\left(40 \mathrm{~g} \mathrm{~mol}^{-1}\right)^{-1} \times 1 \mathrm{eq} \mathrm{mol}^{-1}$

$$
\mathrm{x}\left(365 \mathrm{~d} \mathrm{yr}^{-1} \times 86400 \mathrm{~s} \mathrm{~d}^{-1}\right)^{-1} \times 96485.3 \mathrm{C} \mathrm{mol}^{-1} \mathrm{e}^{-}=35338 \mathrm{C} \mathrm{s}^{-1}
$$

Current needed to be generated in the MECs $=35.3 \mathrm{kA}$

Alkalinity consumption at the anode $=462000 \mathrm{kgNaOH} \mathrm{yr}{ }^{-1} \times\left(40 \mathrm{~g} \mathrm{~mol}^{-1} \times 365 \mathrm{~d} \mathrm{yr}^{-1}\right)^{-1}=31.6 \mathrm{keq} \mathrm{d}^{-1}$

Fraction of wastewater alkalinity load consumed $=100 \% \times 31.6 / 264=12.0 \%$

COD oxidation at the anode

$253 \mathrm{kgCOD} \mathrm{d}^{-1}$ $=35338 \times 86400 \mathrm{~s} \mathrm{~d}^{-1} \times\left(96485.3 \mathrm{C} \mathrm{mol}^{-1} \mathrm{e}^{-}\right)^{-1} \times 8 \mathrm{gCOD} \mathrm{mol}^{-1} \mathrm{e}^{-} \times\left(1000 \mathrm{~g} \mathrm{~kg}^{-1}\right)^{-1}=$

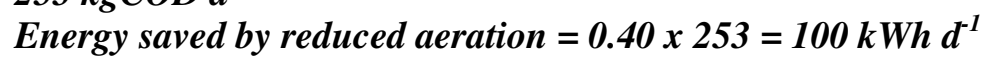


Assuming $1 \mathrm{~V}$ input voltage to the MECs and that hydrogen is generated, which is subsequently converted to methane gas in the anaerobic digester at the plant.

$1.0 \mathrm{~V} \times 35338 \mathrm{~A} \times 24 \mathrm{~h} \mathrm{~d}^{-1}\left(1000 \mathrm{~W} \mathrm{~kW}^{-1}\right)^{-1}=848 \mathrm{kWh} \mathrm{d}^{-1}$

Power consumption to drive MECs $=848 \mathrm{kWh}^{-1}$

Overall increase in electric power consumption $=848-100=748 \mathrm{kWh}^{-1}$

Percentage increase $=100 \% \times 0.748 / 49.9=1.5 \%$

$35338 \mathrm{C} \mathrm{s}^{-1} \times 86400 \mathrm{~s} \mathrm{~d}^{-1} \mathrm{x}\left(96485.3 \mathrm{C} \mathrm{mol}^{-1} \mathrm{e}^{-}\right)^{-1} \mathrm{x}\left(8 \mathrm{~mol} \mathrm{e} \mathrm{mol}^{-1} \mathrm{CH}_{4}\right)^{-1}$

Produced methane $=3955$ molCH$_{4} d^{-1}$

Assuming value of $\mathrm{NaOH}$ is $0.4 € \mathrm{~kg}^{-1} \mathrm{NaOH}$.

$462000 \mathrm{kgNaOH} \mathrm{yr}^{-1} \times 0.4 € \mathrm{~kg}^{-1}+3955 \mathrm{molCH}_{4} \mathrm{~d}^{-1} \times 365 \mathrm{~d} \mathrm{yr}^{-1} \times 0.2222 \mathrm{kWh} \mathrm{mol}^{-1} \times 0.046 € \mathrm{kWh}^{-1}$ $-748 \mathrm{kWh} \mathrm{d}^{-1} \times 365 \mathrm{~d} \mathrm{yr}^{-1} \times 0.08 € \mathrm{kWh}^{-1}=177722 € \mathrm{yr}^{-1}$

Economic savings $=177.7{\mathrm{k} € \mathrm{yr}^{-1}}^{-1}$

Assuming zero interest rate in the calculation of payback period.

$177722 € \mathrm{yr}^{-1} \times 10 \mathrm{yr} \times(35338 \mathrm{~A})^{-1}=50.3 € \mathrm{~A}^{-1}$

Maximum allowed capital cost for 10-year payback period $=50.3 € A^{-1}$

\section{MEC for producing $\mathrm{H}_{2} \mathrm{O}_{2}$}

Assuming Sjölunda WWTP were to be converted to an MBR plant and the a daily backwash with $0.2 \% \mathrm{H}_{2} \mathrm{O}_{2}$ solution was necessary for maintenance cleaning. The ratio between filtrate and backwash flows is 0.004 .

$104000 \mathrm{~m}^{3} \mathrm{~d}^{-1} \times 0.004 \times 2000 \mathrm{gH}_{2} \mathrm{O}_{2} \mathrm{~m}^{-3}=832000 \mathrm{gH}_{2} \mathrm{O}_{2} \mathrm{~d}^{-1}$

Amount $\mathrm{H}_{2} \mathrm{O}_{2}$ that must be generated at the plant $=832 \mathrm{kgH}_{2} \mathrm{O}_{2} \mathrm{~d}^{-1}$

Assuming $\mathrm{H}_{2} \mathrm{O}_{2}$ generation at cathode with $100 \%$ current efficiency

$832000 \times\left(34 \mathrm{~g} \mathrm{~mol}^{-1}\right)^{-1} \times 2 \mathrm{~mol} \mathrm{e}^{-} \mathrm{mol}^{-1} \times\left(86400 \mathrm{~s} \mathrm{~d}^{-1}\right)^{-1} \times 96485.3 \mathrm{C} \mathrm{mol}^{-1} \mathrm{e}^{-}=54654 \mathrm{C} \mathrm{s}^{-1}$

Current needed $=54.7 \mathrm{kA}$

Assuming alkalinity is consumed at anode because an ion exchange membrane is used.

$54654 \times 86400 \mathrm{~s} \mathrm{~d}^{-1} \times\left(96485.3 \mathrm{C} \mathrm{mol}^{-1} \mathrm{e}^{-}\right)^{-1}=48941 \mathrm{eq} \mathrm{d}^{-1}$

Fraction of wastewater alkalinity load consumed $=100 \% \times 48.9 / 264=18.5 \%$

COD consumption at anode $=48941 \mathrm{eq} \mathrm{d}^{-1} \times 8 \mathrm{~g} \mathrm{eq}^{-1} \times\left(1000 \mathrm{~g} \mathrm{~kg}^{-1}\right)^{-1}=392 \mathrm{kgCOD} \mathrm{d}^{-1}$

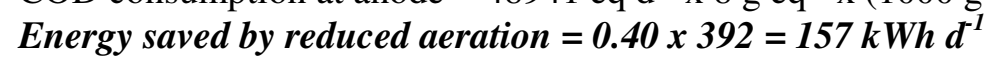

Assuming voltage input of $0.5 \mathrm{~V}$ needed to drive MECs.

$0.5 \mathrm{~V}$ x $54654 \mathrm{~A}$ x $24 \mathrm{~h} \mathrm{~d}^{-1}\left(1000 \mathrm{~W} \mathrm{~kW}^{-1}\right)^{-1}=656 \mathrm{kWh} \mathrm{d}^{-1}$

Power consumption to drive MECs $=656 \mathrm{kWh}^{-1}$

Overall increase in electric power consumption $=656-157=499 \mathrm{kWh}^{-1}$

Percentage increase $=100 \% \times 0.499 / 49.9=1.0 \%$

Assuming value of $\mathrm{H}_{2} \mathrm{O}_{2}$ is $1.14 € \mathrm{~kg}^{-1}$ (US Peroxide 2013).

$832 \mathrm{~kg} \mathrm{~d}^{-1} \times 365 \mathrm{~d}^{-1} \times 1.14 € \mathrm{~kg}^{-1}-462 \mathrm{kWh} \mathrm{d}^{-1} \times 365 \mathrm{~d} \mathrm{yr}^{-1}$ x $0.08 € \mathrm{kWh}^{-1}=331534 € \mathrm{yr}^{-1}$

Economic savings $=331.5 k € \mathrm{yr}^{-1}$

Assuming zero interest rate in the calculation of payback period.

$331534 € \mathrm{yr}^{-1} \times 10 \mathrm{yr} \times(54654 \mathrm{~A})^{-1}=60.7 € \mathrm{~A}^{-1}$

Maximum allowed capital cost for 10-year payback period $=60.9 € A^{-1}$ 


\section{References}

Eurostat (2013). Electricity and natural gas price statistics.

http://epp.eurostat.ec.europa.eu/statistics explained/index.php/Electricity and natural gas_pr ice_statistics (accessed 2013-11-30).

US Peroxide (2013). How much does H2O2 cost? http://www.h2o2.com/faqs/FaqDetail.aspx?fId=25 (accessed 2013-11-30). 